\title{
Improving Speaking Skills Through Acting-out Student-made Play Scripts
}

\author{
Moh. Hadiri. M.Pd
}

STKIP Az Zain Sampang

\begin{abstract}
This research is aimed at improving speaking skills of the eleventh graders of SMK Hidayatul Mubtadien Sampang through acting-out student-made play scripts. This research employed Classroom Action Research. It is consists of 2 cycles. Each cycle there were five meetings. Every cycle consists of four phases in planning, implementing, observing, and reflecting. This research begun with the preliminary study to find the problems. There were 8 students or $33.33 \%$ of students in the class who achieved KKM. The low scores are supported from interview to the English teacher and some students. The result are the students were not motivated, lacked vocabulary, afraid and shy of making mistakes, not enthusiastic, bored, the students seldom to perform in speaking activities, teachercentered, and the students were passive in the teaching and learning process. The result of the study showed that the speaking test in cycle 1 were 13 students or $54.17 \%$ and speaking test in cycle 2 were 20 students or $83.33 \%$ students in the class who achieved KKM and the result of fieldnotes are: interested, enthusiastic, spirit, high motivation, active, brave, confident, and enjoy in speaking activities, and the result of questionnaire that the response of the students were strong and

very strong category. It can be concluded that their speaking skill improved.
\end{abstract}

\section{Keywords: speaking skill, acting play scripts, improving}

\section{Introdution}

Language is a means of communication and interaction between individuals and groups. It plays a central role for people's intellectual, social, and emotional development and a support for successful learning. Language also enables someone else to understand what the speakers want to tell. Therefore, learning a language especially English is expected to help students to be able to use it as a means of communication. Communicating is understanding and expressing information, thoughts and feelings. In order to be able to use English, learners have to master English skills such as listening, speaking, reading, and writing ${ }^{1}$. Although all four skills are equally important, the speaking skill is one of the

\footnotetext{
${ }^{1}$ Depdiknas. Peraturan menteri pendidikan nasional republik Indonesia, (permen nomor 22 tahun 2006), p., 27
} 
important subject to communicate each other through verbally or non verbally in English learning process. During the learning process, learners need to communicate with others in order to express their ideas and feelings.

Tompkins and Hopkinson as cited by Nalti state that the most important general goal in language instruction is to help students learn to communicate effectively with others through oral and written languages, and mastering the art of speaking is the single most important aspect of learning a second or foreign language ${ }^{1}$. The success of which is measured in terms of the ability to carry out a conversation in the language. In classroom setting, the learner's success in learning English should be measured in terms of their ability to converse or speak in English ${ }^{2}$.

Meanwhile, a large percentage of the world's language learners study English in order to develop proficiency in speaking ${ }^{3}$. Speaking is used for many different purposes, and each purpose involves different skills. When we are engaged in discussion with someone, the purpose may be to seek or express opinions, to persuade someone about something, or to clarify information. In some situation, we speak to describe things, to complain about people's behavior or to entertain people with jokes or even anecdotes.

Moreover, language acquisition is considered successful if someone can demonstrate his/her ability to speak in the target language ${ }^{4}$. Therefore, it is essential that the teaching of English be directed to achieve speaking skill. That is why discussion, dialogues, question and answer, drama, games, and role play are recommended in the classroom teaching learning activities.

Concerning the importance of mastering the communicative competence of English based on some linguists' perspective, the national policy through the Regulation of Minister of National Education No 22, 2006, reflects the importance

\footnotetext{
${ }^{1}$ Nalti Nasution. Story-telling technique using puppets to improve the speaking ability of the students of mtsn tangerang ii pamulang. (Unpublished Thesis, Malang: Postgraduate Program, State University of Malang, 2009), p., 1.

${ }^{3}$ Richards, J. C. and Renandya W. A. Methodology in language teaching: an anthology of current practice. (Cambridge: Cambridge University Press, 2002), p., 201.

${ }^{4}$ H. Douglas Brown. Teaching by principle an interactive approach to language pedagogy, second edition (New York: Person Education, 2000), p., 267.
} 
of English in the Standard of Content. In this area, English is taught as a compulsory subject for senior vocational high schools in Indonesia. Based on the Standard of Competence (To communicate in English on the elementary level) and basic of competence (Revealing some kind of heart means) for the speaking skills, senior vocational high school students are expected to be able to express meaningful ideas for both simple transactional (to get something done or get the information) and interpersonal (to get in touch with others for social purposes), formal or informal communication to interact with people in their nearest environment ${ }^{5}$.

Before doing this research, the researcher also did the preliminary study is carried out prior to real classroom action research that the play could not run smoothly. There were only 8 from 24 students or about $33 \%$ of the total number of students who had achieved the minimum passing grade (henceforth KKM), while the rest of the class or about $67 \%$ were still below 75 as KKM.

The fact that the researcher found from English teacher that the researcher have interview. The teacher stated there are many problems that students got low score of speaking. The problems faced by students' the eleventh grade of SMK Hidayatul Mubtadien Sampang are: first, most of the students were not motivated in speaking. In other cases, some of them really wanted to express their ideas and feelings about the material being taught but they did not know how to express their ideas. Second, the students lacked vocabulary to speak in their activities. Third, most of students were afraid and shy of making mistakes. Besides, they were afraid of being laughed at by other students, so they just kept silent in the class. Fourth, students are not enthusiastic and bored in the class.

The low scores above are supported by the result of the interview with some students: first, they like English although they did not know how to speak well and among the four language skills that they want to acquire is speaking. However, they said that speaking is considered as a difficult activity to do, because they felt that finding ideas to be spoken is not easy. They also said that they have lack vocabulary that makes them difficult to speak. Second, they

\footnotetext{
${ }^{5}$ Depdiknas. Peraturan menteri, p., 51.
} 
seldom perform in front of the class by using English. Third, the atmosphere of the class did not support any speaking activity. The teacher used a monotonous teaching style that could make the students bored and lose interest on the subjects which affect the students' ability. Also, the classroom activities tended to be teacher-centered. The students were passive in the teaching and learning process.

Those problems arise because there are some causes which make speaking still need more attentions. They are: Firstly, the teacher rarely conducts real speaking activities in speaking class. Secondly, students have no rehearsal time to perform or to express their own English; Thirdly, the teachers are not aware that variation techniques used in the process of teaching and learning is very important for students. Fourthly, the teacher used a teacher center that could make the students bored and lose interest on the subjects which affect the students' ability. The most serious problem are the students seldom perform to express their ideas in speaking activities.

Referring the facts above, the researcher are highly motivated and interested in conducting classroom action research to improve speaking skills of the eleventh graders of SMK Hidayatul Mubtadien Sampang in the academic year of 2018/2019. There are many techniques that can be assumed to be able to overcome and to give the solutions to the problems or difficulty under speaking skill faced by the students and teachers. One of the techniques to overcome the problems is Acting Play Scripts (henceforth APS); it is used in this research because it is necessary to give an interesting technique to improve students' skill in speaking. Technique is part of role play technique ${ }^{6}$. Besides, ask the students to act out scenes from plays and students will often act out dialogues they have written themselves ${ }^{7}$. This frequently involves them in coming out to the front of the class. APS is suitable to improve the learners' in many situation, it can help

\footnotetext{
${ }^{6}$ Jeremy Harmer. The practice of english language teaching, $3^{\text {rd }}$ edition.( Essex: Longman, 2001), p., 271.

${ }^{7}$ Ibid. 271.
} 
students when get difficult in conversation are liberated ${ }^{8}$. Acting Play Scripts is one of the teaching speaking techniques in which the students have to act out the short written sketches or scenes in group. They have to create their scripts based on the topic given. The teacher provides some vocabularies that include with the topic. Last they have to act their scripts out in front of the class. This technique is suitable with the characteristics of successful speaking activity.

The characteristics of APS are: the learners talk a lot, as much as possible, participation is even, motivation is high, learners are eager to speak because they are interested in the topic and have something new to say about it, and language is of an acceptable level learners express themselves in utterances that are relevant, easily comprehensible to each other, and of an acceptable level of language accuracy ${ }^{9}$. APS also requires social interaction and negotiation of meaning among heterogeneous group members in which they have to help each other.

Acting play scripts for this research just focused on dialoque of speaking in which they are bargaining and invitating expression. The kind of these expression to identify the definition, how to use the expression in daily activities.

Regarding to the previous study with this study. There are some studies conducted earlier in line with role play or acting play scripts. The improving speaking skill in handling guest by using role play technique of the eleventh $\operatorname{grade}^{10}$. The result is that technique affects to the students speaking skills. While, the research about implementing an acting play scripts technique to improve students' speaking skill in which the result is that APS is very effective technique for teaching speaking ${ }^{11}$. Besides, aimed to describe the implementation of teaching speaking by using role play and to describe the students' responses

\footnotetext{
${ }^{8}$ Yuliati, E. (2010). Implementing an acting play scripts technique to improve students' speaking skill. (Yogyakarta, Indonesia: English Education Department Graduate School Sebelas Maret Univesity Surakarta, 2010), p., 4.

${ }^{9}$ Penny Ur. (1991). A course in language teaching: practice and theory (New York: Cambridge University Press, 1991), p., 120.

${ }^{10}$ Gayatri. (2011). Improving speaking skill in handling guests by using role play of the eleventh grade students of hotel accommodation depertment SMK Negeri 3 Blitar. Unpublished Thesis. (Malang, Indonesia: University of Islam Malang, 2007).

${ }^{11}$ Yuliati, E. (2010). Implementing an acting play scripts technique to improve students' speaking skill. (Published Thesis). (Yogyakarta, Indonesia: English Education Department Graduate School Sebelas Maret Univesity Surakarta, 2011)
} 
toward the use of role play speaking in classroom. She is used descriptive qualitative method to know the students' responses ${ }^{12}$. The result of the research both teacher and students activein the teaching and learning process. In addition, Hadi (2019) also employed a role play technique in teaching speaking to see the effectiveness of the technique ${ }^{13}$. He used the qualitative data were gained from the observations and the interviews with both the English teacher and the students. The data were transformed into field notes and interview transcripts. Meanwhile, the quantitative data were gained from the speaking tests that were administered before the action implementation and at the end of every cycle.

Based on the statement above, the researcher formulates the research problem as follows, "How can the speaking skills be improved through Acting Play Scripts of the eleventh graders of SMK Hidayatul Mubtadien Sampang?"

\section{Method}

This research employs Classroom Action Research Design. According to Carr and Kemmis as cited by Nalti, action research is a form of collective self-reflective enquiry undertaken by participants (teachers, students) in social situations in order to improve the rationality and justice of their own social or educational practices, their understanding of these practices, and the situations (of institutions) in which these practices are carried out ${ }^{14}$. The gathered information from the research is aimed to gain insight, develop reflective practice, affect positive changes in school environment, and improve students' outcomes and the lives of those involved.

This research focused on the eleventh grade of students' SMK Hidayatul Mubtadien Sampang in academic year 2018-2019 and located in Pangilen village of Sampang sub-district, Sampang regency. This school consists of three classes; ten grade 34 students, eleventh grade 24 students, and twelfth grade 26 students.

\footnotetext{
${ }^{12}$ Rachmawati, Y. Teaching speaking by using role play of the fifth grade students of minu kh. mukmin sidoarjo, (http://lppm.stkippgri-sidoarjo.ac.id/files/Teaching-Speaking-by-Using-RolePlay-for-Elementary-School-Students.pdf, 2013).

${ }^{13} \mathrm{Hadi}, \mathrm{K} . \mathrm{L}$. Using the role-play technique to improve the speaking skills of grade xi students of sman 1 panggang in the academic year of 2014/2015,(http://eprints.uny.ac.id/16156/1/Kunto\%20Laksono\%20Hadi\%2010202244025.pdf, 2015)

${ }^{14}$ Nalti Nasution. Story-telling, P., 56.
} 


\section{Planning}

At this stage, researcher planned a suitable model of APS to improve students' speaking skill and determined criteria of success.

Providing the Strategy. In the conduction of this study, the researcher used APS. There were some steps in APS: first, students are divided into six groups that each group consists of four students; second, the teacher give topic to the students in the group; third, students discuss with their group; fourth, students make scripts based on the topic; fifth, students prepare before performing the scripts; sixth, students perform in front of the class by turn.

The innovation of this research are: researcher provided list of vocabulary and video that related with topic in every cycle activities, and do not need memorized scripts before performing in front of the class.

Designing Lesson Plan of Speaking Skill. The lesson plan was designed as teacher's guideline to conduct the teaching activity. Before conducting teaching and learning activity, the lesson plans were under basic of competence 2.5 in English syllabus which includes the following items: the instructional objectives, instructional material and media, the procedures in teaching-learning activities, and assessment.

Determining the instructional objective is important since it helps the teacher to achieve the criteria of success. Moreover, the instructional objective guides the teacher to use the time schedule effectively, so the objective can be achieved successfully. Meanwhile, general instructional objective of the teachinglearning in this study was to enable the students to express ideas in dialogue in bargaining and invitating.

Preparing instructional material and media is also important since they give effect in students' achievement. Both material and media can facilitate the students to learn the language as well as motivate them to take part actively in the learning activities. In this research, the instructional materials were taken from English books and other available sources such as internet. 
During the activities the teacher checks the students' comprehension in speaking skill through APS, and their comprehension on the topic as it is sated in the lesson plan.

Preparing Instructional Materials. Preparing materials plays an important role in the teaching and learning process. It is important for the teacher to select and prepare appropriate materials based on their students' needs and levels. The teacher selects the English speaking from some resources such as books, the internet, and so on which are suitable for senior vocational high school students' level.

Preparing Instruments. The instruments prepared in this study are field notes, test, and questionnaire to obtain the information during the teaching and learning activities through APS. The explanations of all instruments in detail are visualized in the section of observing action.

Criteria of Success. This study deal with improving students' speaking skills through APS. The criteria of success in this study, the implementation of APS in teaching learning speaking has succeeded or failed. In relation to this criterion, $75 \%$ of the students should gain score equal to or higher than 75 and the mean score of students in speaking test in equal to or higher than 75 as KKM at the school. This implies that the action is successful. It is used to to decide whether the action has to be continued to the next cycle(s) or stopped. The criteria of success are based on the result of test after the action.

\section{Implementing}

In this study, researcher was as designer of the action of students' speaking skill. The implementation of APS in this action study drawn in the lesson plan and it is planned in the cycles. The implementation of APS in this research was in two cycles because cycle 1 was unsuccessful in order that the cycle 2 was conducted. Each cycle consisted of five meetings which was the first four meeting focus on applying APS for improving the students' speaking skill while the last meeting was for speaking test. 
The implementation of APS under CAR was conducted on April $11^{\text {th }}, 13^{\text {th }}$, $18^{\text {th }}, 20^{\text {th }}$, and $22^{\text {nd }} 2019$ in the cycle 1 while for the cycle 2 was conducted on April $25^{\text {th }}, 27^{\text {th }}$, May $2^{\text {nd }}, 4^{\text {th }}$, and $6^{\text {th }} 2019$.

\section{Observation}

The observation was conducted during the process of the teaching and learning through APS activities. So, the researcher use of some instruments to get accurate and reliable data, such as field note, test, and questionnaire.

\section{Reflection}

Reflection is the process of analyzing data to determine how far the data collected have shown the success of the technique and the strategy in solving the problems faced by the students. The way to analyze is by comparing the results with the criteria of success. In the field notes, the observer noted what he saw about the teaching and learning activities in speaking skills which most of the students were interest, enthusiasm, spirit, high motivation, active, brave, confident, and enjoy. For the speaking test, the researcher uses to give score based on the scoring rublic as stated in lesson plan. The researcher got the scores when the students perform the scripts in speaking test cycle 1 and cycle 2 . For the questionnaire, if more than $50 \%$ or more than 12 students stated strongly agree and agree for each item of questionnaire, it would be considered that there was positive response from the students. Therefore, it was considered that there was positive response from the students about the implementation of APS.

The intention of reflection is to see what has been successful and has not been successful within the action. In other words, reflection is intended to see the success or the failure of what has been done in the previous action or during the action. As stated before that there were two criteria of success whether in need of moving to the next cycle or not in which they are: $75 \%$ of the students should gain score equal to or higher than 75 and the mean score of students in speaking test in equal to or higher than 75 as KKM at the school. 


\section{Result}

The Students' Activities and Participantion in the Teaching and Learning Process

This research there were two cycles. Each cycle consist of five meeting includes questionnaire in the end of cycle 2 . The cycle 1 was on April, $11^{\text {th }}$ until April, $22^{\text {nd }}$ 2019. The result of cycle 1: the mean score of speaking test 1 the class derived 74.16 in which there were 13 students who passed KKM 75. It shows that there are some improvements from the preliminary study mean score. It can be seen from the preliminary study mean score (67.21) to the mean score of the speaking test 1 (74.16). It improves 6.95 (74.16-67.21).

Next, to know the class percentage of students' score who passed KKM (75) in speaking test 1 . The result of class percentages which passed KKM was 54. $17 \%$. It means that in the cycle 1 of CAR, there are 13 students who passed KKM and there were 11 students score are below KKM. The students' improvements which pass KKM are $20.84 \%(54.17 \%$ - 33.33\%). It can be inferred that a process of APS had been improved enough in students' speaking.

Based on the field notes and test in cycle 1, students' participation are interest, enthusiastic, spirit, and high motivation in the overall activities of the teaching and learning process. However, few of them had not shown their high motivation. So, it is still needed more improvement because it could not achieve yet $75 \%$ and as the target criteria of success CAR. Then, the researcher needed to revise the plan and applied it to improve students' speaking skill through APS in cylce 2 .

The cycle 2 was on April, $25^{\text {th }}$ until May, $6^{\text {th }}$ 2016. The result of mean score speaking test 2 , the mean score of speaking test 2 is 80.02 . It means that there were some students' improvement scores 5.84 (80-74.18) from the mean of speaking test 1 (74.18).

Next, to know the class percentage was $83.33 \%$. It means that in the cycle 2 there were 20 students who pass KKM and there were only 4 students are below KKM. The class percentage of speaking test 2 shows some improvements from 
the previous test; the improvement is 50\% (83.33\%-33.33\%) from the preliminary study and $29.16 \%$ from the class percentage of speaking test $1(83.33 \%-54.17 \%)$.

The result of cycle 2 based on the test and the field notes. Most of the students respond the teacher actively and teaching learning process is done very runwell. The students felt happy in applying the APS activity such activity was very enjoyable and they got fun.

The researcher gave questionnaire after finishing speaking test 2. There are five questions that students gave check list that provided by the researcher which consits; strongly agree, agree, disagree, and strongly disagree. The researcher felt satisfied because the students have significant improvement scores from preliminary study, speaking test 1 , and speaking test 2 in students' speaking skill. In this cycle, all five components speaking skills: pronunciation, grammar, vocabulary, fluency, and comprehension improved evenly. The students achieve the target criteria of success CAR. Therefore, the researcher decided to stop the CAR because it had already succeeded.

\section{The Students' responses on the Implementation of APS}

In relation to the students' response toward the implementation of APS strategy, the students expressed their opinion trough questionnaire which denoted that there were positive responses from students. the administration of the collecting data through questionnaire after conducted the speaking test 2 or on May, $6^{\text {th }} 2019$. The questionnaire distributed to all students who joined the teaching and learning process through APS, the questionnaire had five questions which the result were analyzed on based on the basis of the students' answer of the questions.

For the first item, 33\% of students felt strongly agree toward speaking subject, $42 \%$ of students felt agree about it, $17 \%$ of students felt disagree in learning speaking, and 3\% of students felt strongly disagree toward speaking subject. For second item, $50 \%$ of the students felt strongly agree an activity of APS to improve their speaking was very helpful, $33 \%$ of the students felt agree that APS could help them to improve their speaking, $17 \%$ of students felt disagree to improve their speaking, and there is no students felt strongly disagree. For third 
item, $46 \%$ of the students felt strongly agree in learning speaking through APS, $38 \%$ of the students felt agree to master the speaking through APS and $8 \%$ of the students felt disagree teaching speaking trough it, and 8\% students felt strongly disagree about it. For next item, 38\% of the students felt strongly agree in mastering speaking through APS, 33\% of the students felt agree to improve their speaking trough APS, $21 \%$ of the students felt disagree in the activity, and $8 \%$ students felt strongly disagree to speak trough APS. For last item, Fifth, 63\% of the students were strongly agree in the teacher's style during the action, $29 \%$ of the students felt agreed, and $8 \%$ of the students felt disagree, and no one students felt strongly disagree about the teacher's style. It indicated that the teacher had done the action well.

\section{Disscusion}

Considering the result of the two cycles, the researcher discuss some points related to implementation of APS in teaching speaking intended to improve students' speaking skill. In this research, the researcher used CAR. Its purpose was to know whether there was improvement of students' achievement in speaking or after being taught through APS.

Before the implementation of the strategy, it appeared that the students' speaking product were not satisfactory. It was probably occurred because of lacked vocabulary, students center, afraid makes mistakes, and shy. The low students' speaking skill that was seen from the result of preliminary study was effected by many factors. After the researcher conducted the APS, the speaking score improved. The students' improvement on each aspect such as pronunciation, grammar, vocabulary, fluency, and comprehension.

APS is a way to make students easier to express their idea by making scripts or scenes. Usually students need the time to prepare their scripts before they perform. This statements is supported that We can ask our students to act out scenes from plays and students will often act out dialogues they have written themselves ${ }^{15}$. This frequently involves them in coming out to the front of the

\footnotetext{
${ }^{15}$ Jeremy Harmer. The practice of English, p., 271.
} 
class. APS is suitable to improve the learners' in many situation, it can help students when get difficult in conversation are liberated.

In addition, the process speaking proposed (Grauberg, 1997, p. 201) speaking in the classroom and speaking in real life. In the classroom, speaking is used to learn the language as training pronunciation, and it is also to communicate with other students and teachers, to be sociable with them, to discuss certain topic, etc. In real life, speaking skill also plays such a massive role, speaking is important for carrier success ${ }^{16}$.

In the meantime, the researcher presented the result of research and the analysis of the data collected which were conducted through preliminary study, speaking test 1 , and speaking test 2 .

In relation to the results of this research, the researcher found that there was significant difference between the students' speaking who was taught by using APS and those taught before using APS. It meant that APS could help the students in improving their speaking. It could also help the teacher to improve the students motivation and interest in speaking. Teaching speaking through APS could stimulate the students in improving their speaking and force them to think and be creative. So, the students' achievement that were taught speaking through APS was better than who were taught speaking before using APS for the eleventh grade students of SMK Hidayatul Mubtadien Sampang.

Considering the limited data gathered from questionnaire, the researcher believes that the implementation of APS is useful for the students. Most of the students could adapt very well and enjoyed in implementing the strategy. Additionaly, learning speaking trough APS very well and strong category. Furthermore, the students confessed that their speaking skills could improve after implementing the APS as it is in line with the result of the speaking test.

In addation, most of students admitted that they fell enjoy in joining the teaching and learning process during implementing the APS. Referring to the

\footnotetext{
${ }^{16}$ Grauberg, W. The elements of foreign language teaching. (Clevedon: Multilingual Matters, Ltd, 1997), p., 201.
} 
responses of the students could best interpreted that the use of such a technique and strategy makes the students feel enjoy in the teaching and learning process.

To sum up, the result of analysis shows that APS could be applied to improve the students' speaking skill. This technique also stimulates the students' awareness on their own speaking so that they could produce the better speaking product. During the implementation, the students had shown great enthusiastic to the technique presented. Therefore, it can be concluded that the implementation of APS was successfully to improve speaking skills of the eleventh graders of SMK Hidayatul Mubtadien Sampang.

\section{Conclusion and Suggestion}

\section{Conclusion}

After APS is implemented in the teaching speaking skills, it can be drawn conclusion that APS can improve the students' ability in speaking skill of the eleventh graders of SMK Hidayatul Mubtadien Sampang.

This technique also successfully encourages them to actively in teaching and learning process. It can be seen from the mean score in the speaking test cycle 2 is 80.02 and the class percentages which pas $\mathrm{KKM}$ are $83.33 \%$. It means there are 20 students whose score pass KKM and there are 4 students are below KKM. The speaking test cycle 2 has fulfilled the target of CAR success, that is above $75 \%$ students could pass KKM. The use of APS to improve students' speaking is an alternative way, very useful, and interesting in learning teaching English especially in improving students' speaking.

In addation, in terms of the students' involvememt in teaching and learning process are: interest, enthusiasm, spirit, high motivation, active, brave, confident, and enjoy in overall activities of the teaching and learning process were very good. It means also that the criteria of success in terms of their participation in the teaching and learning process had been achieved.

The implementation of APS in the presents study follows these procedures: first, asking the students to make group. Second, asking them to discuss the topic given by the researcher. Third, asking the students to make 
162 - 163 | Tafhim Al-‘Ilmi, September 2019

scripts conversation. Fourth, having the students a group presentation related to the result of APS they have made. Last, asking the each group to perform in front of the class by turn.

In short, the result of APS to improve students' speaking skill in SMK Hidayatul Mubtadien Sampang had already succeeded in two cylces.

\section{Suggestion}

Referring to the conclusion, the following are some suggestions addressed to the English teachers and future researchers.

The English teachers of SMK Hiadayatul Mubtadien Sampang and the others school whose students have similar classroom problems, characteristics, and situations with SMK Hiadayatul Mubtadien Sampang that the process of APS could be used as an alternative teaching way to improve the students' speaking. In addition, the teacher can make the teaching and learning process interesting in order to make the students easy to understand and interest in learning English.

The future researchers can use the result of this study as reference to other researches with different skills or subject. The researcher believed that thesis is far from being perfect. So the researcher will accept good suggestions and constructive criticism to make this thesis perfect. The researcher also hopes that the thesis will be useful and contribute some valuable thing to the rese: herself and future researcher.

\section{References}

Brown, H.D. (2000). Teaching by principle an interactive approach to language pedagogy, second edition New York: Person Education.

Depdiknas. (2006). Peraturan menteri pendidikan nasional republik indonesia: permen nomor 22 tahun 2006.

Gayatri. (2011). Improving speaking skill in handling guests by using role play of the eleventh grade students of hotel accommodation depertment SMK Negeri 3 Blitar. (Unpublished Thesis). Malang, Indonesia: University of Islam Malang. 
Grauberg, W. (1997). The elements of foreign language teaching. Clevedon: Multilingual Matters, Ltd.

Hadi , K.L. (2015). Using the role-play technique to improve the speaking skills of grade xi students of sman 1 panggang in the academic year of 2014/2015, (http://eprints.uny.ac.id/16156/1/Kunto\%20Laksono\%20Hadi\%20 10202244025.pdf)

Harmer, J. (2001). The practice of english language teaching, $3^{r d}$ edition. Essex: Longman.

Nasution, N. (2009). Story-telling technique using puppets to improve the speaking ability of the students of mtsn tangerang ii pamulang. (Unpublished Thesis). Malang: Postgraduate Program, State University of Malang.

Rachmawati, Y. (2013). Teaching speaking by using role play of the fifth grade students of minu $k h$. mukmin sidoarjo, (http://lppm.stkippgrisidoarjo.ac.id/files/Teaching-Speaking-by-Using-Role-Play-for-ElementarySchool-Students.pdf).

Richards, J. C. and Renandya W. A. (Eds.). (2002). Methodology in language teaching: an anthology of current practice. Cambridge: Cambridge University Press.

Ur, P. (1991). A course in language teaching: practice and theory New York: Cambridge University Press.

Yuliati, E. (2010). Implementing an acting play scripts technique to improve students' speaking skill. (Published Thesis). Yogyakarta, Indonesia: English Education Department Graduate School Sebelas Maret Univesity Surakarta. 